\title{
A VIRGEM MARIA NO SURREALISMO PORTUGUÊS: VISUALIDADE PLÁSTICA E POÉTICA
}

Michele Coutinho Rocha ${ }^{1}$

Resumo: O artigo tem como objetivo estudar a representação da Virgem Maria no Surrealismo português, considerando as suas múltiplas abordagens plásticas e poéticas. O estudo destas representações evidencia uma linguagem subversiva e irónica que questiona o ideal de feminilidade da sociedade patriarcal movida por ideais religiosos, mas também os instintos puros da maternidade.

Palavras-chave: Surrealismo Português, Pintura, Feminino.

\section{THE VIRGIN MARY IN PORTUGUESE SURREALISM: PLASTIC AND POETIC VISUALITY}

Abstract: The article aims to study the representation of the Virgin Mary in Surrealism Portuguese, considering its multiple approaches plastic and poetic. The study of these representations shows a subversive and ironic language that questions the ideal of femininity of patriarchal society driven by religious ideals, but also the pure instincts of motherhood.

Keywords: Portuguese Surrealism, Painting, Virgin Mary.

No contexto do Surrealismo, a imagem da Virgem Maria exerce uma profunda atração, tanto na literatura como nas artes plásticas. A figura da Virgem, sendo o ideal de feminilidade da Igreja Católica, contém um forte potencial imagético, propício à criação de imagens subversivas. Num tom provocador e irónico, por vezes deliberadamente insultuoso e ofensivo, o ícone da maternidade imaculada converte-se num símbolo de luta contra os valores morais de uma sociedade patriarcal movida pela ideologia religiosa, umas vezes como vítima despersonalizada dos valores patriarcais, outras como figura subversiva ou musa inspiradora, procurando escapar aos papéis pré-estabelecidos dessa sociedade (CONLEY, 1996). Em L'Immaculée Conception (BRETON, ÉLUARD, 1991), o texto automático escrito por Paul Éluard e André Breton, a Virgem Maria - intermediária privilegiada entre a dimensão humana e a divina - surge como metáfora para a concepção imaculada de textos automáticos.

$\mathrm{Na}$ poética surrealista portuguesa, Políptica de Maria Klopas, dita Mãe dos Homens (CESARINY, 2005, p. 24-37) de Mário Cesariny² - denominada pelo autor como "história

\footnotetext{
${ }^{1}$ Investigadora de Pós-Doutoramento em Ciências da Arte na Faculdade de Belas Artes da Universidade de Lisboa.

2 Mário Cesariny (Lisboa, 1923-2006) participa na fundação do Grupo Surrealista de Lisboa, de que se afasta em 1948, para formar um novo grupo Os Surrealistas. Colabora ativamente na redação dos textos coletivos e nas ações empreendidas pelo grupo. A densa obra poética do autor destaca-se no panorama da poesia portuguesa contemporânea. Nas artes plásticas, assume uma atitude permanente de experimentação, com a introdução de novas técnicas.
} 
dadá de Nossa Senhora das Dores" (1997, p. 51) - expõe de uma forma negativa e destruidora o mito da Nossa Senhora. A Virgem Maria, que colocou o seu corpo à disposição dos desígnios de Deus, é apresentada como uma vítima passiva da vontade divina: "Àquela / que em vida / foi desapossada / foi morta / descida / crucificada / e ao terceiro dia / não foi nada [...]" (2005, p. 24). Predestinada a acolher no seu ventre a semente de Deus, ao contrário das outras mulheres, é alguém que não vivencia verdadeiramente a maternidade: "Teresa pediu as dores / nossa senhora não / [...] / Madalena teve um filho / nossa senhora não [...]." (2005, p. 26). Confrontada com a anunciação do Anjo São Gabriel que irá conceber no seu ventre "O senhor nu, que vem morrer", Maria não questiona, apesar de não compreender. A obediência e submissão religiosa inibem o espírito crítico e impossibilitam a manifestação da vontade: "Maria Klopas / não percebeu / mas perguntar / não se atreveu” (2005, p. 27-28).

Ao nível plástico, Cruzeiro Seixas ${ }^{3}$, em Anunciação a Virgem Maria Manuela de 1972 (fig. 1), converte a anunciação da concepção imaculada de Maria num prenúncio de violência e profanação. $\mathrm{Na}$ composição, um insólito objeto de madeira com uma espiral metálica, projeta-se sobre uma minúscula figura feminina em devoção, iluminada pela luz da Lua. Numa obra anterior, intitulada Anunciação a Maria de África (fig. 2), o anúncio da concepção de Maria assume uma expressão erótica, numa exaltação da sexualidade e do prazer.

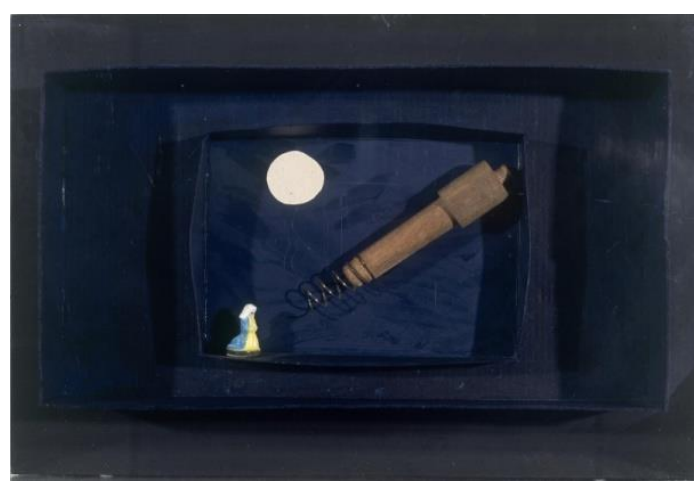

Fig. 1. Cruzeiro Seixas, Anunciação à Virgem Maria Manuela, 1972; imagem de cerâmica, madeira e metal sobre caixas de cartão, 26 × 38 x 8,5 cm; col. F.C.M., Famalicão.

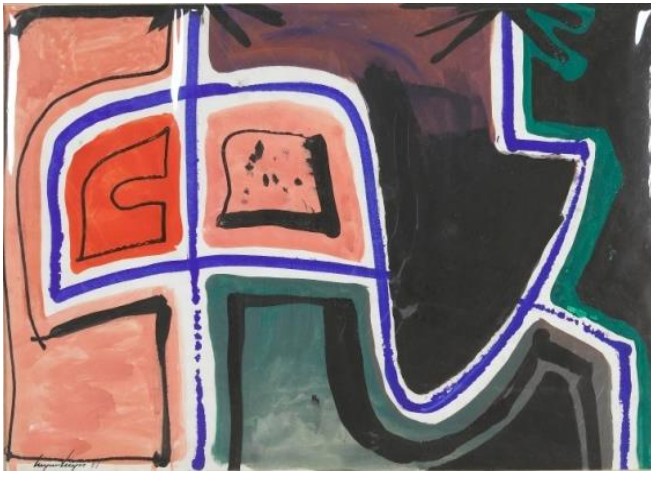

Fig. 2. Cruzeiro Seixas, Anunciação a Maria de África, 1958; guache sobre papel, 17 x $24 \mathrm{~cm}$; col. Biblioteca Nacional.

\footnotetext{
${ }^{3}$ Cruzeiro Seixas (Amadora, 1920) adere ao Neo-realismo, que abandona em 1946, para assumir o Surrealismo, como expressão liberta de imposições estéticas e ideológicas. Participa nas duas exposições do grupo Os Surrealistas e em algumas ações coletivas. Em 1951 alista-se na marinha mercante e viaja intensamente, acabando por se fixar em Angola, onde permanece até à guerra colonial. A sua obra poética e plástica (sobretudo desenhos e objetos) denota uma forte ligação com o continente africano.
} 
No mesmo sentido, Eduardo Luiz ${ }^{4}$ subverte a imagem imaculada da Virgem Maria ao deslocar a tónica do sagrado para o domínio do erotismo e da transgressão. Em Nossa Senhora do Losango (fig. 3), a pureza da brancura virginal assume a forma de cortina, entreaberta, que simultaneamente oculta e revela um corpo feminino, num convite ao conhecimento e à descoberta. Um pequeno losango vermelho sobre a zona erógena coloca a figura no registo erótico. No plano do fundo, a afirmação do negro, espesso e opaco, em oposição ao branco virginal, ainda não manifestado, introduz uma dimensão inquietante e perturbadora, como prenúncio da manifestação obscura e perversa do desejo.

Obras como A Relíquia Herética de 1973 (fig. 4) aprofundam a ideia de profanação do corpo feminino como imagem do sagrado. Na composição, um tecido branco, debruado com uma renda delicada, assume o contorno de um corpo, como metáfora da beleza e pureza feminina. De uma forma assumidamente herética, tal como o título sugere, Eduardo Luiz confere à imagem a aparência de relíquia religiosa. O tecido branco com o contorno feminino evoca a imagem do sudário sagrado, o tecido imaculado que envolveu o corpo de Cristo crucificado. A associação da imagem feminina ao tecido imaculado, como expressão da pureza, inocência e virgindade, tem subentendido o desejo de profanação. Eduardo Luiz, tal como Bataille (BATAILLE, 1988), concebe a beleza, perfeição e pureza da nudez feminina como objeto erótico, que desperta no sujeito desejos incontidos de profanação e posse. A delimitação do espaço, recorrente na obra do autor, reforça o sentido de propriedade, encerra o objeto feminino precioso e frágil, na esfera privada e íntima do sujeito.

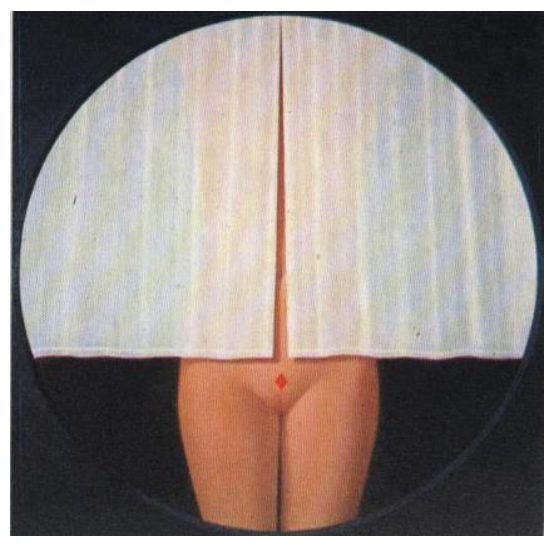

Fig. 3. Eduardo Luiz, Nossa Senhora do Losango, 1977; óleo sobre tela, 80 x $80 \mathrm{~cm}$; col. particular.

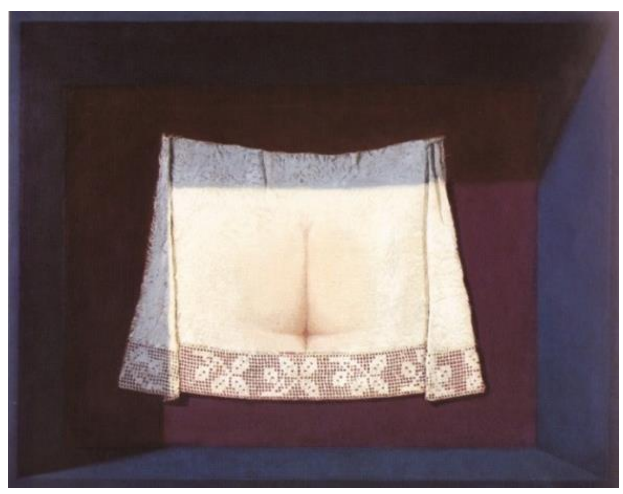

Fig. 4. Eduardo Luiz, A Relíquia Herética, 1971; óleo sobre tela, 73 x $92 \mathrm{~cm}$; col. particular.

\footnotetext{
${ }^{4}$ Eduardo Luiz (Braga, 1932-1988) frequenta o curso de Pintura na Escola de Belas-Artes do Porto. Parte para Paris em 1958, como bolseiro da Fundação Calouste Gulbenkian, cidade onde passaria a residir até à data do seu falecimento. Participa em inúmeras exposições individuais e coletivas. Em Paris, desenvolve uma pintura que parte do figurativo, para lhe introduzir novos significados e incongruências.
} 
O tema da Virgem Maria surge igualmente numa série de desenhos de Mário Botas ${ }^{5}$ intitulados Les êxtases de la Vierge, realizados em 1976 - numa época de grande conturbação política e social - com um sentido crítico e irónico muito acentuado, próximo dos ideais surrealistas. Nos desenhos, a tinta-da-china com legenda colada na parte inferior, Mário Botas recupera o mito da Virgem Maria, imagem idolatrada pela Igreja Católica, para colocar uma série de interrogações num registo provocador. Partindo da temática da Virgem Maria, o ícone cristão da maternidade imaculada, o autor questiona o ideal de feminilidade da sociedade patriarcal e expõe a hipocrisia moral e religiosa contida nesta concepção, nomeadamente a apropriação e subjugação da mulher, baseada na negatividade do corpo, da sexualidade e do prazer.

O título Les êxtases de la Vierge sugere uma ligação com a problemática da histeria, uma das temáticas centrais da poética surrealista. A obra de Salvador Dali, Le Phénomène de lêxtase (1933), imagem emblemática de beleza convulsiva, apresenta uma fotomontagem de faces femininas em estado de êxtase.

Ao associar a imagem da Virgem Maria ao estado de êxtase, Mário Botas pretende, de uma forma subversiva e provocatória, identificar o êxtase religioso com o decorrente do desejo sexual, como forma de atingir o discurso patriarcal e religioso. Jean Martin Charcot, considerado por Breton como estando na origem do debate sobre histeria, identificou uma fase no ataque histérico onde estados de êxtase religioso se misturam frequentemente com manifestações de erotismo (LOMAS, 2001, p. 55-57).

A contradição suscitada pelo título tem continuidade na relação entre texto e imagem. À semelhança do que acontece frequentemente na obra surrealista, os desenhos de Mário Botas conjugam texto e imagem, de forma pouco convencional. O texto alusivo ao culto da Virgem Maria, colado na parte inferior da composição, funciona como catalisador, intensificando o poder subversivo e irónico da imagem. A contradição entre texto e imagem reforça o carácter provocatório dos conteúdos. Desta forma, o autor desloca o discurso religioso para a temática da sexualidade e do erotismo.

\footnotetext{
${ }^{5}$ Mário Botas (Nazaré, 1952-1983) frequenta o curso de Medicina, profissão que nunca chega a exercer. A doença prolongada, que o vitimou precocemente, condicionou a sua carreira e determinou a opção exclusiva pela pintura. A aproximação à literatura e poética surrealista e aos seus precursores, bem como o contacto com surrealistas como Cruzeiro Seixas, Mário Cesariny Manuel Casimiro, Raúl Perez e Paula Rego, foi determinante no desenvolvimento de um discurso pictórico singular, marcadamente poético e irónico.
} 
Um dos desenhos (fig. 5) tem como tema a devoção da família cristã à imagem da Virgem Maria. Mário Botas, num registo minucioso e irónico, questiona o ideal feminino da sociedade patriarcal de tradição cristã. No primeiro plano, os diferentes elementos do núcleo familiar cumprem rigorosamente o papel que lhes é atribuído. O chefe da família, forte e altivo no seu traje de militar, ocupa o centro do plano. Atrás a figura materna, irrepreensível no seu papel de mãe e esposa, eleva-se acima dos outros elementos, numa clara aproximação à imagem da Virgem Maria, exemplo máximo de devoção e sublimação dos instintos maternais, enquanto ao lado, uma personagem com contornos de extraterrestre, sugere a presença do autor.

Num segundo plano, os objetos de devoção, perfeitamente enquadrados no espaço doméstico, funcionam igualmente como peças de mobiliário. À esquerda um armário está assinalado com o número um, símbolo do princípio criador: o centro místico, fonte e fim de todas as coisas. Por cima, em letras minúsculas, "Vision of Paradise" reforça o carácter sagrado do objeto, enquanto em baixo um mecanismo de roldanas testemunha a atividade divina.

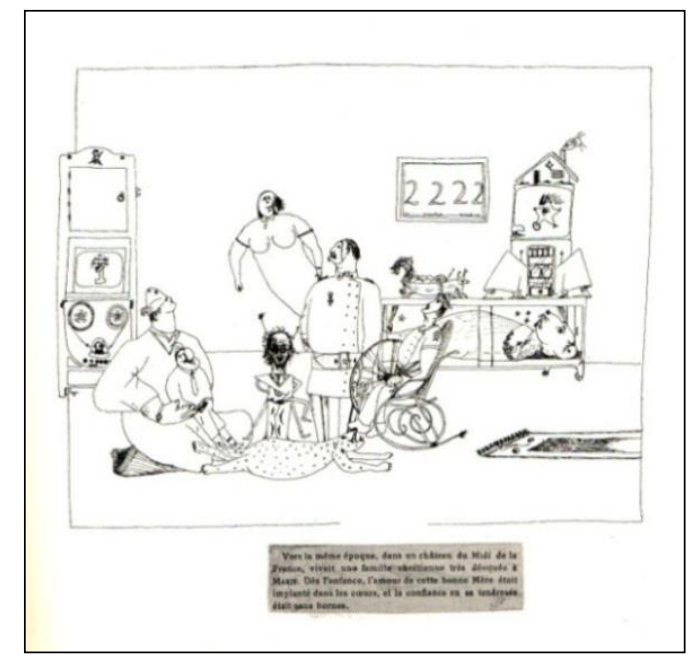

Fig. 5. Mário Botas, Les êxtases de la Vierge, 1976 ; desenho a tinta-da-china sobre papel com colagem de legenda, 28,2 x 27,7 cm; col. F.C.M.M.B., Nazaré.

À direita um objeto ambíguo, com características humanas, sugere a presença da Virgem Maria. Num registo irónico e provocador, Mário Botas reúne uma série de símbolos conotados com a Virgem e com a maternidade. O número dois, símbolo da dualidade, assinala o princípio feminino. Uma estrela de cinco pontas, um dos atributos da Virgem, ocupa o lugar do rosto. A parte superior da figura, em forma de casa, evoca o 


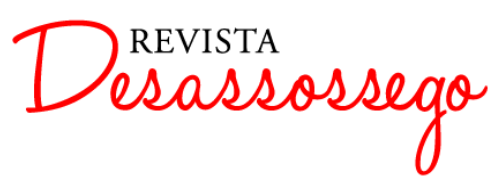

espaço materno, o sentimento de refúgio e proteção do seio maternal. A Virgem Maria é também conhecida como a casa de Deus.

De acordo com a tradição cristã, a Virgem Maria foi visitada pelo anjo Gabriel que lhe anunciou que fora escolhida pelo Senhor para conceber no seu ventre imaculado, livre do pecado original, o seu Filho Divino, de nome Jesus (LEEMING, PAGE, 1994, p. 154155). No desenho, o ventre da Virgem Maria transforma-se numa cristaleira com cálices no seu interior.

Ao transformar o corpo da Virgem Maria num objeto utilitário que cumpre uma determinada função, Mário Botas põe a descoberto, a problemática da apropriação e subjugação do corpo feminino por uma sociedade patriarcal que legitima o discurso da Igreja Católica. Tal discurso subordinou as mulheres à sua natureza, em especial ao papel reprodutor. O corpo feminino, destituído de sexualidade e prazer, devia ser reservado para a fecundação por parte do marido. À semelhança de Aristóteles, que considerava a mulher um mero recetáculo do sémen masculino, São Tomás de Aquino - o grande teólogo da Igreja Católica - afirma que a mulher não é a responsável pela criação, mas apenas um veículo passivo do nascimento, enquanto a função ativa e vital da procriação era masculina (BARING, CASHFORD, 1993. p. 521). A Virgem Maria, exemplo máximo da sublimação dos instintos maternais, representa esse ideal de feminilidade. Ao colocar o seu corpo imaculado à disposição dos desígnios de Deus, torna-se no recetáculo inviolado da semente divina.

Ao representar o corpo da Virgem Maria como um objeto despersonalizado desprovido de individualidade e vontade - um recetáculo passivo da vontade de Deus Mário Botas, à semelhança de Cesariny no poema Políptica de Maria Klopas [...], transforma o ícone da maternidade imaculada numa imagem denunciadora da sociedade patriarcal e dos seus valores, fundados no primado do masculino. Valores, que em Portugal se mantiveram profundamente arreigados até meados dos anos 70 .

A ideologia do Estado Novo, sob forte influência católica, reafirmou a autoridade masculina, insistiu nas estruturas familiares tradicionais, baseadas em relações de género retrógradas, em conceções patriarcais de feminilidade e maternidade que pressupunham a destituição da sexualidade e do prazer mantendo apenas a função da procriação. Apesar da aparente valorização da maternidade e do trabalho doméstico como funções de utilidade social, "as mulheres do Estado Novo foram discriminadas através de leis que as colocavam sob a autoridade masculina, lhes proibiam inúmeras profissões e lhes atribuíam, sem 
alternativas, espaços específicos de atuação dos quais não podiam sair" (PIMENTEL, 2001, p. 400). A legislação do Estado Novo com a justificação da diferença biológica - a maternidade - promoveu a desigualdade de direitos políticos, laborais e sociais entre homens e mulheres (2001, p. 399-416).

Jorge Vieira ${ }^{6}$, numa colagem (fig. 6) de 1947, satiriza a concepção de maternidade do Estado Novo. Na composição duas figuras femininas, à semelhança da Virgem Maria que acolheu no seu ventre a semente divina, recebem de braços abertos e de forma imaculada o filho que cai do céu como uma graça divina. No mesmo sentido, Mário Henrique Leiria ${ }^{7}$ num desenho (fig. 7) sensivelmente da mesma data, expõe de forma irónica e corrosiva, a sexualidade destituída de erotismo e prazer, direcionada exclusivamente para a função reprodutora.

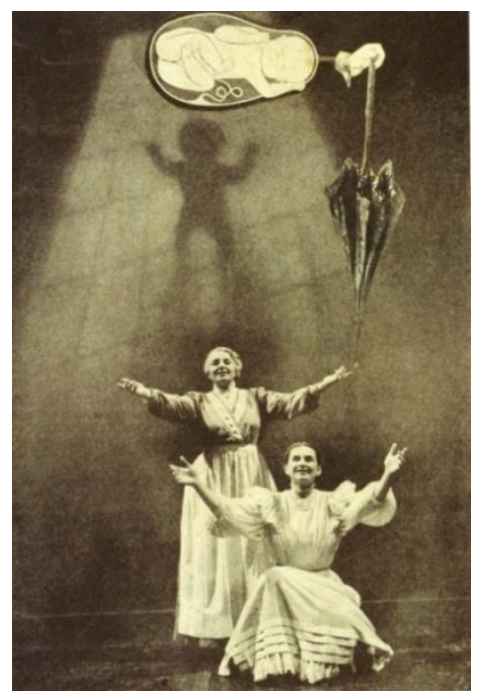

Fig. 6. Jorge Vieira, Sem titulo, 1947; colagem sobre ilustração, 19 x 12,9 cm; col. Museu do Chiado, Lisboa.

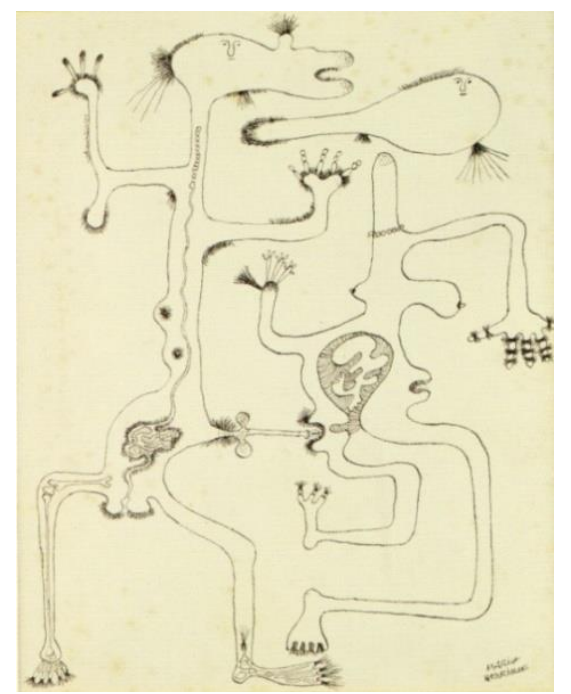

Fig. 7. Mário Henrique Leiria, Sem titulo, c. 1949-1950; tinta-da-china sobre papel, $32 \mathrm{x}$ $25,5 \mathrm{~cm}$; col. particular.

Num outro desenho (fig. 8) que integra a série Les êxtases de la Vierge, Mário Botas transforma a imagem da Virgem numa espécie de mecanismo de conceder graças. O texto que acompanha o desenho refere a homenagem prestada pelos fiéis no mês consagrado a Maria. Na tradição cristã, a Virgem, tendo uma origem simultaneamente terrena e

\footnotetext{
${ }^{6}$ Jorge Vieira (Lisboa, 1922-1998) formado em escultura, estabelece uma estreita ligação com surrealistas como António Pedro e Mário Henrique Leiria, entre outros, tendo participado em algumas atividades coletivas. A atividade artística, iniciada no desenho estende-se à colagem e sobretudo à escultura em terracota. 7 Mário Henrique Leiria (Lisboa, 1923-1980) integra o grupo Os Surrealistas; assina a maioria dos seus manifestos e textos coletivos e participa nas principais manifestações públicas. A sua obra, marcadamente poética, inclui colagens, objetos e desenhos, mas destaca-se sobretudo pela convergência entre a expressão verbal e plástica, traduzida em poemas, novelas-colagem ou desenhos que relacionam a palavra e a imagem.
} 
sobrenatural, é considerada uma intermediária privilegiada entre a dimensão humana e a divina (BARING, CASHFORD, 1993, p. 553). Neste sentido, Mário Botas sugere um mecanismo giratório, onde uma figura com antenas transmissoras marca a presença da Virgem Maria. À semelhança de um mecanismo moderno, artificial e perfeito, com capacidades sobre-humanas, a Virgem Maria foi concebida e concebeu de forma imaculada, sem a intervenção humana.

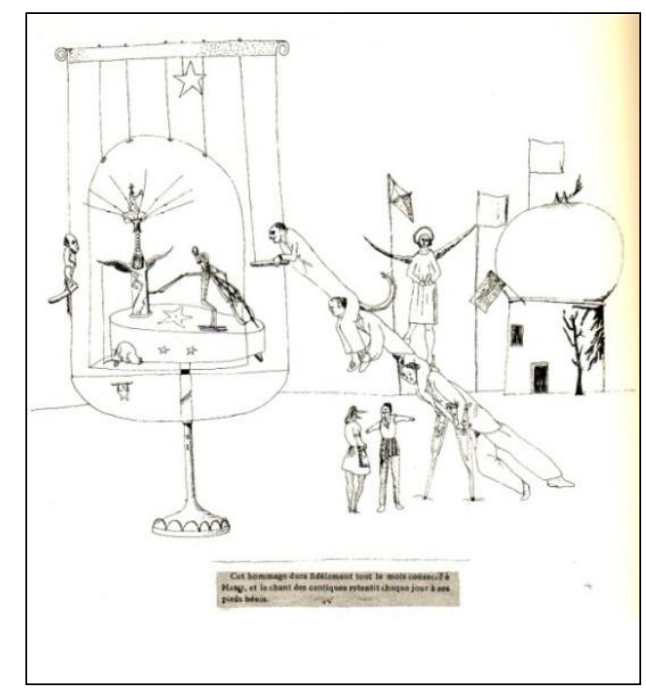

Fig. 8. Mário Botas, Les êxtases de la Vierge, 1976; desenho a tinta-da-china sobre papel com colagem de legenda, 27,5 x 26,9 cm; col. F.C.M.M.B., Nazaré.

Comparar a imagem feminina a um mecanismo é algo comum no Pré-surrealismo e no Surrealismo. Integra-se dentro de um discurso que visa sobretudo surpreender e chocar o espectador. Em Voilá la femme Picabia associa a ideia de mulher contida no título, à imagem de uma máquina. Em Dancer ou Danger: L'Impossibilite ou limpossible Man Ray, através de um mecanismo de roldanas, joga com o duplo significado que a letra $\mathrm{C}$ assume: Dancer ou Danger, a mulher como expressão de sedução ou como ameaça. Na obra de Marcel Duchamp, La mariée mise à nu par ses célibataires, même (Le Grand Verre), o feminino é conotado com uma máquina desencadeadora de desejo. Mais tarde, Hans Bellmer, em Mitrailleuse en état de grace, associa um mecanismo com características femininas à violência das armas.

À semelhança do desenho anterior (fig. 5), Mário Botas constrói uma imagem irónica e crítica da figura da Virgem e dos seus atributos, mas também da vivência da fé e 
da hipocrisia religiosa. Ao lado, um conjunto de fiéis organizados de forma instável, em sinal de obediência e sacrifício, presta homenagem à Virgem. Ironicamente, no mês dedicado a Maria onde todos os desejos deveriam estar subjugados à razão, a demonstração de sacrifício e fé religiosa aproxima-se de uma forma fálica.

O tema da degradação moral, da hipocrisia religiosa e social está igualmente presente num outro desenho (fig. 9), de forma ainda mais explícita. O texto colocado na parte inferior refere a peregrinação das crianças ao parque para venerarem a estátua da Santa Virgem. Na interpretação de Mário Botas, a imagem da Virgem Maria, colocada sob um pedestal, assume uma forma profana e sexualizada. No parque, crianças e adultos encontram-se de forma furtiva e provocatória, numa mistura promíscua de símbolos infantis, figuras repugnantes e corpos expostos sexualizados.

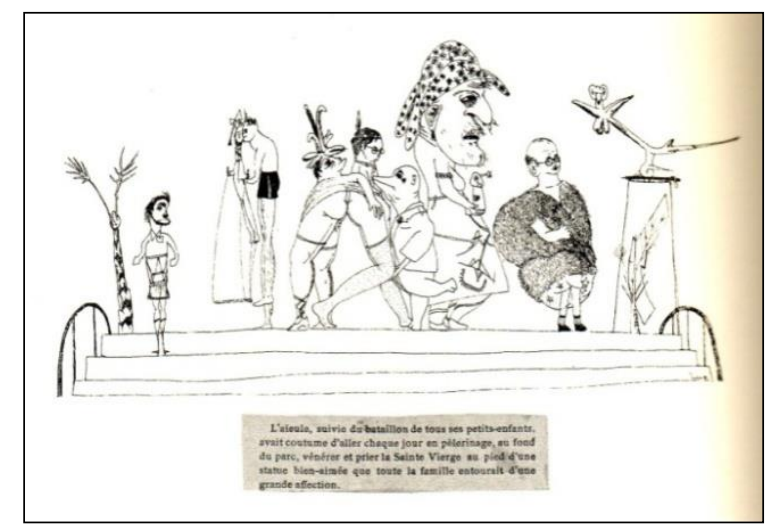

Fig. 9. Mário Botas, Les êxtases de la Vierge, 1976; desenho a tinta-da-china sobre papel com colagem de legenda, $28 \times 19$ cm; col. F.C.M.M.B., Nazaré.

Num outro desenho (fig. 10), Mário Botas expõe de forma sarcástica e crítica as concepções católicas que determinam a negatividade do corpo - em particular do corpo feminino - da sexualidade e do prazer. O texto que acompanha o desenho refere a Assunção da Virgem Maria, no momento em que a sua alma se eleva aos céus.

À semelhança dos desenhos anteriores, a representação profundamente irónica contrasta com a seriedade e rigor imposta pelo texto. Mário Botas apresenta uma série de símbolos que remetem para a temática da ascensão e renascimento mas subverte a sua representação 


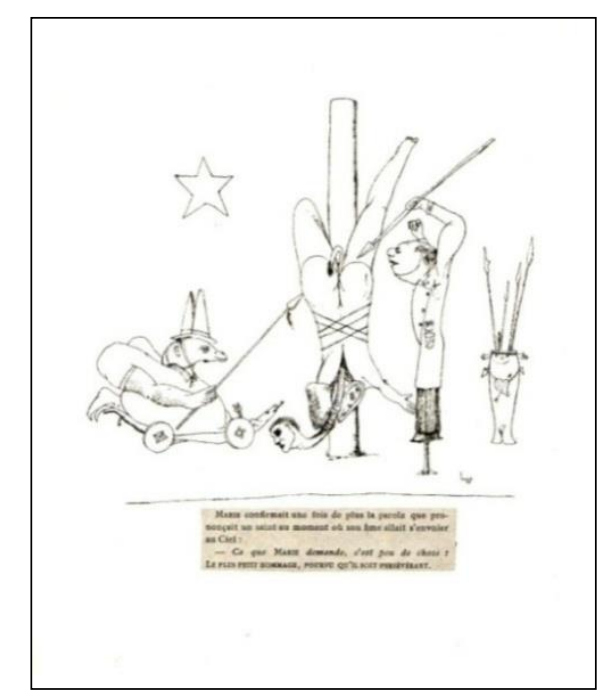

Fig. 10. Mário Botas, Les êxtases de la Vierge, 1976 ; desenho a tinta-da-china sobre papel com colagem de legenda, $27,8 \times 25,3 \mathrm{~cm}$; col. F.C.M.M.B., Nazaré,

No desenho, um corpo com características femininas, suspenso de cabeça para baixo num tronco de madeira, é fustigado por lanças. Do seu interior liberta-se um estranho ser com cabeça humana, num processo transformativo que evoca a libertação da crisálida do casulo e a metamorfose em inseto. Mário Botas aproxima a ideia de metamorfose, como passagem de um estado larvar embrionário para uma outra condição de existência, da ideia de morte e renascimento. O ser que abandona o corpo, à semelhança do inseto que sai da crisálida ou do invólucro protetor, é um símbolo de ressurreição, contém a pureza original do ser renascido. Neste sentido sugere também uma representação da alma, o princípio vital que abandona o corpo, o invólucro material, para aceder num movimento ascensional a uma existência celestial. As asas, símbolo de elevação, reforçam esta ideia de desmaterialização ou libertação da alma ou espírito imaterial das condições materiais de existência.

A propósito da temática da ascensão e ressurreição da Virgem Maria, Mário Botas representa de forma irónica a antinomia corpo-alma que caracteriza o pensamento cristão e que tem como base as ideias negativas relativas ao corpo, em particular ao corpo feminino. $\mathrm{Na}$ tradição cristã, à alma ou espírito, essência imaterial do ser, opõe-se o corpo corruptível e mortal como um excesso a controlar, disciplinar e conter. A negatividade do corpo, intensificada pelo Cristianismo, tem a sua origem no pecado original. Eva, ao sucumbir à tentação da serpente instigando Adão a provar o fruto proibido, é a grande responsável pela expulsão do Paraíso Terrestre. A sua ação marca o fim do estado de comunhão 
perfeita, de unidade e harmonia com o divino, designa a queda da imortalidade primordial e inicia o trágico destino da condição humana de nascimento e morte (BARING, CASHFORD, 1993, p. 487).

Da perda da inocência, da clareza e simplicidade primordiais, resulta a consciência do corpo e a revelação da carne. Depois do pecado original, a nudez do corpo é experimentada como vergonha, como marca da sexualidade e degradação da matéria. Uma consciência que advém da dissolução da unidade primordial entre o corpo e o espírito. $O$ Corpo, matéria corruptível e mortal deve estar subjugado ao controle e à racionalidade da mente. Eva, considerada uma substância inferior e por isso mais sujeita a cair na tentação, representa o Corpo e a Matéria enquanto Adão representa a Mente e o Espírito. Como consequência, a tradição cristã associa a mulher ao corpo e o homem à mente, e daí a subjugação da mulher ao homem, amplamente difundida na teologia católica (1993, p. 529).

De forma semelhante Mário Botas apresenta um corpo com características femininas em representação da matéria e um ser com características masculinas em representação da alma ou espírito. Desta forma o autor expõe a antinomia corpo-alma que caracteriza o pensamento cristão e que tem como base as ideias negativas relativas ao corpo, em particular ao corpo feminino.

A representação do corpo feminino, com marcas de sexualidade, suspenso de cabeça para baixo num tronco de madeira e fustigado por lanças, sugere as práticas da Inquisição, onde a tortura do corpo significava a salvação da alma. O medo do corpo da mulher, em particular da sexualidade feminina, cuja perversa sedução se teme, está presente nas acusações de bruxaria e heresia. Eva, e por extensão todas as mulheres, descritas como moralmente mais fracas, mais instintivas e portanto mais sexuais, eram tidas como uma porta de entrada do espírito do mal, capaz de levar o homem à tentação. O corpo, em particular o corpo feminino mais sujeito ao pecado da carne, deveria ser sacrificado ao espírito. Na composição Mário Botas representa o corpo feminino com uma cauda de animal, como que possuído por forças maléficas.

Num outro desenho (fig. 11), com a inscrição “Ave Maria, Gratia Plena!”, Mário Botas, mantendo o mesmo registo irónico, põe em causa os valores sublimes da maternidade. Maria, contrariando todas as representações tradicionais da Virgem e do Menino, transforma-se numa figura subversiva, poderosa e dominadora.

O tema da Virgem com o Menino surge igualmente numa colagem (fig. 12), onde Mário Botas converte a tradicional imagem da adoração da Virgem e do Menino numa 
exaltação da sociedade de consumo. De forma irónica, a Virgem com o Menino ao colo culmina na imagem publicitária de um conhecido refrigerante, aureolado com uma coroa de estrelas, o atributo tradicional da Virgem.

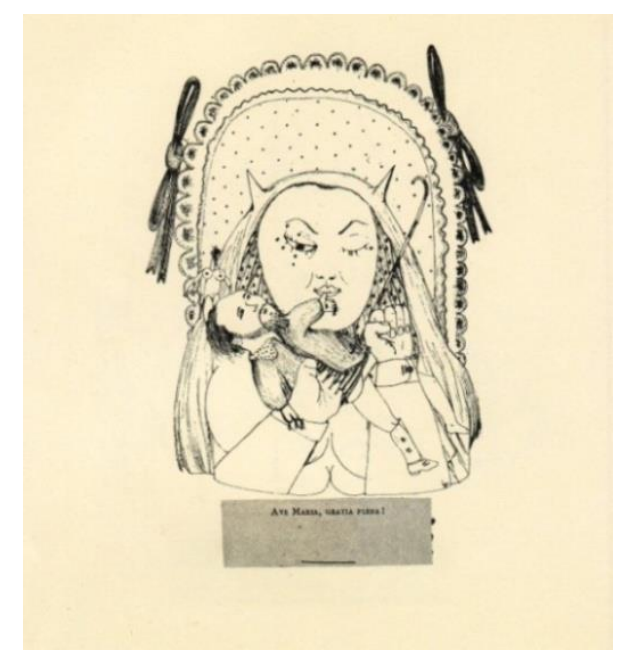

Fig. 11. Mário Botas, Les êxtases de la Vierge, 1976 ; desenho a tinta-da-china sobre papel com colagem de legenda, 27,2 x 26,7 cm; col. F.C.M.M.B., Nazaré.

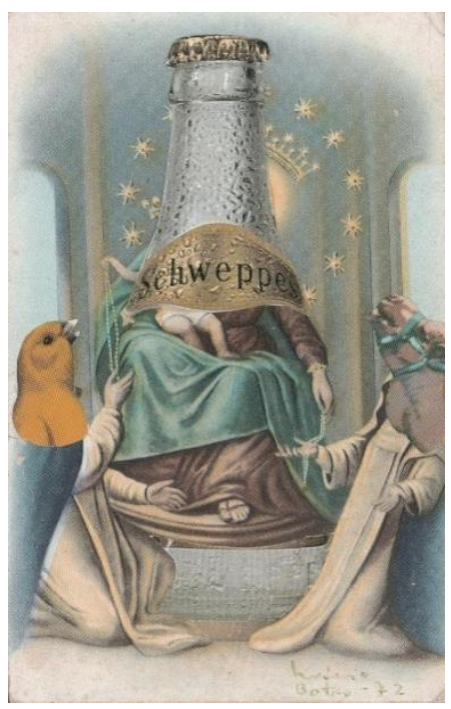

Fig. 12. Mário Botas, Sem título, 1972 ; colagem s. papel, $13,2 \times 8,3 \mathrm{~cm}$; col. F.C.M., Famalicão.

A representação da imagem da Virgem Maria - figura idolatrada pela Igreja Católica, símbolo de um certo ideal de feminilidade - como uma figura subversiva e dominadora, afrontando os valores patriarcais, não é inédita no Surrealismo. O quadro de Max Ernst, La Vierge corrigeant l'enfant Jesus devant trois témoins: André Breton, Paul Éluard et le peintre de 1926, representa de forma surpreendente a Virgem espancando o Menino Jesus diante de testemunhas, onde se inclui o autor e o próprio espectador. A auréola do Menino, sinal sagrado da divindade, encontra-se caída no chão. Com o divino suspenso, o Menino, à semelhança de uma criança como tantas outras, sujeita-se à repreensão materna.

Em Les êxtases de la Vierge (fig. 11), o ícone da maternidade imaculada, da obediência e da humildade assume uma imagem, simultaneamente, perversa e sensual. O véu, atributo da Virgem, símbolo do recolhimento e de intimidade com Deus, revela dois chifres, numa aproximação às forças demoníacas. A sexualização do corpo, materializada nos seios descobertos e na expressão provocadora do olhar, contrasta com a imagem tradicional da Virgem Imaculada, livre do pecado original. No ombro uma pequena figura feminina nua reforça a ideia do assumir do corpo, da sexualidade e do prazer. O trono profusamente decorado com rendas e laços sugere a ambiência de volúpia e intimidade da alcova, mas também do berço materno. O domínio absoluto da figura feminina contrasta com a 
fragilidade da figura masculina que ocupa o lugar do Menino. De forma irónica o Menino é substituído pela imagem de um homem-marioneta subjugado à vontade feminina, que sugere a presença do autor.

De certa forma, Mário Botas restitui à imagem da Virgem Maria, símbolo patriarcal da humildade e da obediência a Deus, o poder das antigas divindades femininas matriarcais. O bastão, sinal de autoridade e poder, reforça a dimensão suprema da figura. Ao contrário da imagem da Virgem Maria, exemplo máximo da sublimação e harmonia perfeita dos instintos maternais, as antigas divindades comportam um duplo significado. $\mathrm{O}$ arquétipo da "magna mater", fonte primordial da criação, para além da dimensão positiva, protetora e geradora de vida, contém igualmente uma componente negativa, devoradora e opressiva. A Grande Deusa Mãe não só dá origem à vida, como também recebe no seu útero de morte tudo o que dele nasceu (NEUMANN, 1963, p. 149).

$\mathrm{Na}$ representação a figura materna comporta igualmente uma dupla dimensão: sensual e sedutora, mas também manipuladora, opressiva e castradora, ao prolongar de forma excessiva as funções maternais, travando o desenvolvimento do indivíduo. $O$ homem-marioneta que ocupa o lugar do Menino reflete esta atitude involutiva e destrutiva de regresso ao materno, numa negação da individualidade que impede o assumir do eu.

O entendimento do materno como expressão regressiva e degenerativa, que oprime e limita a expansão do indivíduo, está igualmente presente na obra de Mário Henrique Leiria. Num conjunto de desenhos o materno assume uma conotação opressiva e devoradora. Em dois desenhos intitulados Maternidade (fig. 13 e 14) o materno assume a imagem de um corpo disforme, constituído por um aglomerado de formas arredondadas ou ovoides que evocam os tecidos moles e os fluidos orgânicos implicados no processo gestativo, mas também membros ou órgãos com ramificações sanguíneas, unidos entre si por ligações umbilicais ou filamentos nervosos, que se comprimem ou sobrepõem num tecido denso e impenetrável.

O corpo gestante, entendido como território de convergência e emanação em autores como Vespeira ou Manuel Patinha, converte-se numa interioridade viscosa, repugnante e labiríntica. Em baixo, a frase "...entretanto, continuava a tricotar o casaquinho azul", ridiculariza os instintos puros e sublimes da maternidade. 


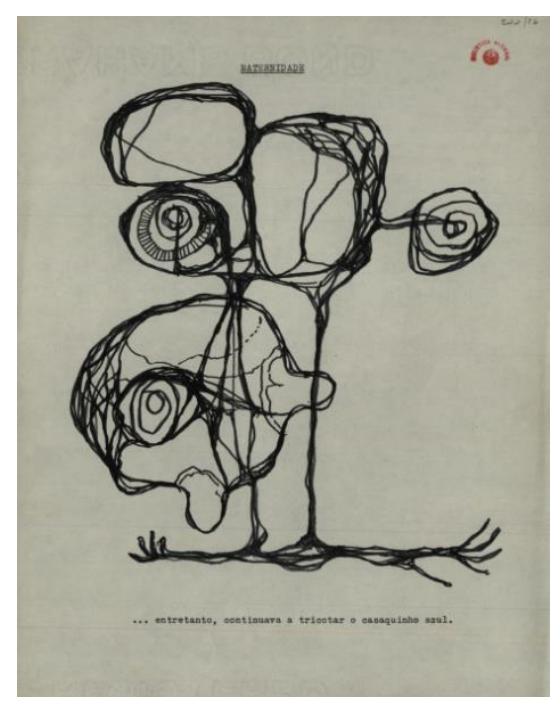

Fig. 13. M. Henrique Leiria, Maternidade, n. d. ; tinta-da-china sobre papel, 26,7 x 20,8; col. Biblioteca Nacional, Lisboa.

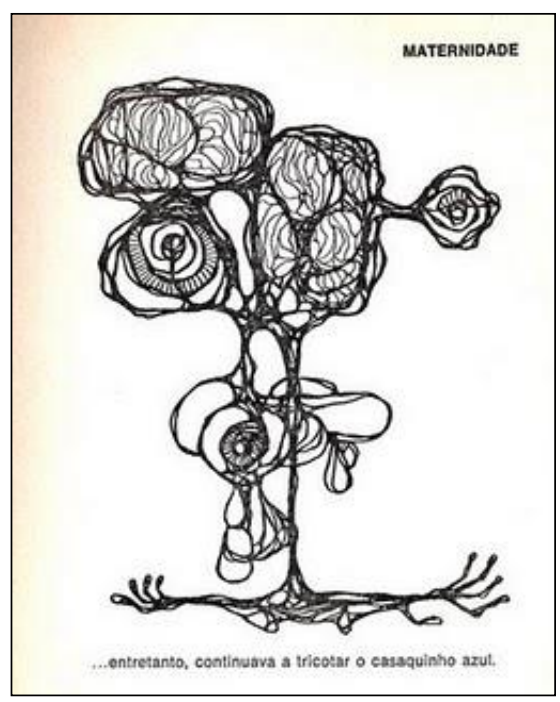

Fig. 14. M. Henrique Leiria, Maternidade, n. d. ; tinta-da-china sobre papel, 26,7 x 20,8; col. Biblioteca Nacional, Lisboa.

A noção de interioridade tenebrosa e labiríntica surge implícita numa das imagens que integra a novela-colagem Pas pour les parents, de 1951 (fig. 15). Mário Henrique Leiria recorre a uma ilustração científica que sugere formas biomórficas ou tecidos orgânicos ampliados, com finos filamentos que se cruzam numa densa teia impenetrável, para reforçar a ideia de intransponibilidade, dificuldade e estagnação.

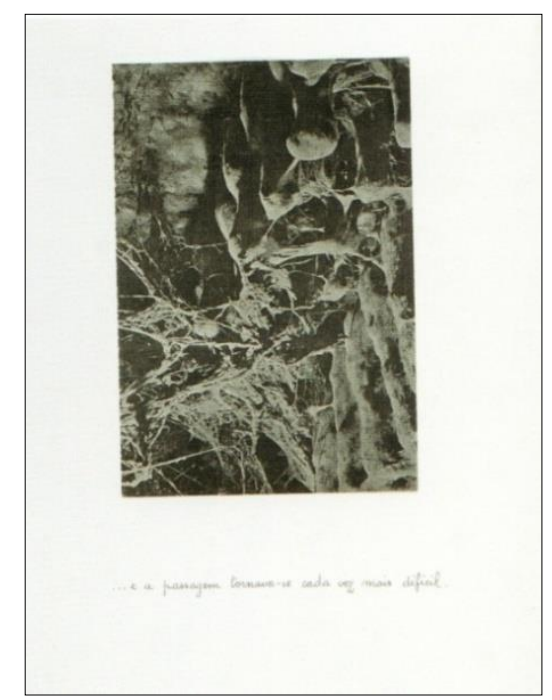

Fig. 15. Mário Henrique Leiria, Pas pour les parents, 1951; novela-colagem, 32,6 x 25,2 cm; col. Biblioteca Nacional, Lisboa.

Em baixo a frase “.... e a passagem tornava-se cada vez mais difícil” intensifica a ameaça da retenção ou imobilização do sujeito. Num dos poemas, Mário Henrique Leiria 
descreve o encontro com o feminino como um lugar simultaneamente "tenebroso e cantante":

[...] eu sei / que há um lugar por descobrir / um lugar tenebroso e cantante / como uma ponte de velhos manequins/ aí / o teu corpo / dois seios despedaçados / e o vento só o vento / soprado através dos / teus cabelos [...] (CUADRADO, 1998, p. 159).

A representação da Virgem Maria e por extensão do materno assume no contexto do Surrealismo português uma expressão marcadamente provocadora e irónica. Autores como Cruzeiro Seixas e Eduardo Luiz subvertem a imagem da Virgem Maria, inserindo-a num registo de violência e profanação ou conferindo-lhe uma conotação sexual. No mesmo sentido, Mário Botas, partindo da imagem da Virgem Maria, símbolo de um ideal imaculado de feminilidade, desmonta o discurso católico patriarcal contido nesta concepção - nomeadamente a problemática da apropriação e subjugação do feminino, baseada na negatividade do corpo, da sexualidade e do prazer - ao mesmo tempo que questiona os instintos puros e sublimes da maternidade.

\section{Referências:}

BARING, Anne; CASHFORD, Jules. The Myth of the Goddess: Evolution of an Image. London: Arcana Penguin Books, 1993.

BATAILLE, George. O Erotismo. Trad. João Bénard da Costa. Lisboa: Edições Antígona, 1988.

BRETON, André; ÉLUARD, Paul. L'Immaculee Conception [1930]. Paris: J. Corti, 1991.

CESARINY, Mário. A Intervenção Surrealista, Lisboa: Assírio e Alvim, 1997.

CESARINY, Mário. "Políptika de Maria Klopas dita Mãe dos Homens”. In Manual de Prestidigitação, Lisboa: Assírio e Alvim, $2^{a}$ ed., 2005, p. 24-37.

CONLEY, Katharine. Automatic Women: The Representation of Woman in Surrealism. Lincoln and London: University of Nebraska Press, 1996.

CUADRADO, Perfecto E. A Única Real Tradição Viva. Antologia da Poesia Surrealista Portuguesa. Lisboa: Assírio \& Alvim, 1998.

LEEMING, David; PAGE, Jake. Myths of the Female Divine: Goddess. Oxford University Press, 1994. 
LOMAS, David. "The omnipotence of Desire: Surrealism, Psychoanalysis and Hysteria. In Jennifer Mundy". Surrealism. Desire Unbound. London: Princeton University Press, 2001, p. $55-77$.

NEUMANN, Erich. The Great Mother: An Analysis of the Arquetype. Princeton: University Press, 1963.

PIMENTEL, Irene Flunser. História das Organizações do Estado Novo. Lisboa: Temas e Debates - Actividades Editoriais, 2001.

Data de recebimento: 19/04/2017

Data de aprovação: 15/12/2017 